\title{
Long-term impact of farm management and crops on soil microorganisms assessed by combined DGGE and PLFA analyses
}

\section{Fabio Stagnari ${ }^{1+}$, Giorgia Perpetuini ${ }^{1+}$, Rosanna Tofalo ${ }^{1 *}$, Gabriele Campanelli $^{2}$, Fabrizio Leteo ${ }^{2}$, Umberto Della Vella ${ }^{1}$, Maria Schirone ${ }^{1}$, Giovanna Suzzi ${ }^{1}$ and Michele Pisante ${ }^{1}$}

${ }^{1}$ Faculty of BioScience and Technology for Food, Agriculture and Environment, University of Teramo, Mosciano Sant'Angelo, Italy

${ }^{2}$ Consiglio per la Ricerca e la Sperimentazione in Agricoltura - Unità di Ricerca per I'Orticoltura (CRA - ORA), Monsampolo del Tronto, Italy

\section{Edited by:}

Javier Carballo, University of Vigo,

Spain

Reviewed by:

Sergio Enrique Pasteris, Universidad

Nacional de Tucumán, Argentina

Giorgio Giraffa, Consiglio per la

Ricerca e la Sperimentazione in

Agricoltura, Italy

*Correspondence:

Rosanna Tofalo, Faculty of

BioScience and Technology for

Food, Agriculture and Environment,

Via C.R. Lerici 1, Mosciano S.

Angelo 64023, Italy

e-mail: rtofalo@unite.it

tThese authors have contributed

equally to this work.
In the present study, long-term organic and conventional managements were compared at the experimental field of Monsampolo del Tronto (Marche region, Italy) with the aim of investigating soil chemical fertility and microbial community structure. A polyphasic approach, combining soil fertility indicators with microbiological analyses (plate counts, PCR-denaturing gradient gel electrophoresis [DGGE] and phospholipid fatty acid analysis [PLFA]) was applied. Organic matter, $\mathrm{N}$ as well as some important macro and micronutrients ( $\mathrm{K}, \mathrm{P}, \mathrm{Mg}, \mathrm{Mn}, \mathrm{Cu}$, and $\mathrm{Zn}$ ) for crop growth, were more available under organic management. Bacterial counts were higher in organic management. A significant influence of management system and management $x$ crop interaction was observed for total mesophilic bacteria, nitrogen fixing bacteria and actinobacteria. Interestingly, cultivable fungi were not detected in all analyzed samples. PLFA biomass was higher in the organic and Gram positive bacteria dominated the microbial community in both systems. Even if fungal biomass was higher in organic management, fungal PCR-DGGE fingerprinting revealed that the two systems were very similar in terms of fungal species suggesting that 10 years were not enough to establish a new dynamic equilibrium among ecosystem components. A better knowledge of soil biota and in particular of fungal community structure will be useful for the development of sustainable management strategies.

Keywords: organic and conventional food, microbial groups, fungal community, soil fertility indicators, long-term soil management

\section{INTRODUCTION}

The market of organic foods in Europe is growing and it has evolved from a niche to the mainstream; in this contest Italy represents the fourth largest market for organics (Hughner et al., 2007). Organic agriculture was firstly defined by the European Union regulation (CEE/2092/91 and CEE1804/99) (Lairon, 2009) and it is considered to be more environmentally sound than intensive agriculture, which is dependent on the routine use of herbicides, pesticides, and inorganic nutrient for crops and animals production (Bengtsson et al., 2005). Generally, organic farmers do not use conventional inputs: pests are naturally controlled and crops are rotated and diversified (Reganold et al., 2010). In such systems, plant growth and ecosystem productivity are based on the natural availability of plant nutrients, the use of green manure and organic soil amendments (Berry et al., 2002). Several advantages, related to soil quality including higher water holding capacity, cation exchange capacity (CEC), lower bulk density, and build-up of nutrient stocks can be obtained, with a favorable impact on vegetable production (Bulluck et al., 2002). Other benefits include $\mathrm{pH}$ stabilization and faster water infiltration rate (Stamatiadis et al., 1999). One fundamental aspect for soil quality, which has not been appropriately considered till some years ago, is represented by "biodiversity," normally indicated as the variability of the living forms, soil fauna, flora, vertebrates, birds, and mammals within an habitat or a management system of a territory involved in agricultural activity. A larger microbial biodiversity significantly affect all the smallscale processes that underlie many environmentally important functions such as mineralization of nitrogen, phosphorus and sulfur, as well as soil aggregates formation and pesticides degradation (Bonilla et al., 2012; Zhang et al., 2012; Lorenzo et al., 2013). However, the precise definition of soil microbial community structure, diversity and functions remains still a black box. Most soil microbes withstand laboratory cultivation so, very few have been isolated, cultured and identified, and directly related to their function in agroecosystems (Fierer and Jackson, 2006). A recent project called TerraGenoma (Vogel et al., 2009) highlighted the huge variability in soil microbial community as affected by space, time and management (organic vs. conventional), confirming the complexity of this ecosystem. In recent years, the approaches for studying soil microbiota have moved from biochemical and microbiological determinations (enzyme activities, microbial biomass and respiration coefficients) to the investigation of bacterial diversity and microbial communities 
structure (Hill et al., 2000). No single method can give a reliable description of the total community, consequently a combined multidisciplinary approach would offer the opportunity to correlate information, and to overcome and minimize drawbacks, arising from culture-dependent and independent methods. Moreover, to provide a more complete picture of microbial diversity and a deeper understanding of the interactions in soil microbial "sociology" statistical analyses are needed to integrate the results obtained with these methods (Reganold and Dobermann, 2012).

In light of the above, it is very important to understand the impact of the agricultural systems on microbial biodiversity and consequently on soil fertility, through the use and the definition of appropriate biological, chemical, and physical indicators (Mader et al., 2002; van Diepeningen et al., 2006; Reganold et al., 2010). To develop a sustainable agricultural model, based not only on crop productivity but also on ecological principles, long-term field experiments are necessary. Some studies have compared conventional to organic farming systems, but the obtained results are often controversial because of the interactive effects of several farming practices, soil quality, crop varieties, time of harvesting etc. (Reganold et al., 2010). Only very few long-term studies have been conducted under Mediterranean conditions. Recently, Campanelli and Canali (2012) investigated the effect of a long-term organically managed farming system for vegetable production in central Italy, on yield and quality of six species, within the project Monsampolo Organic Vegetable (MOVE).

The aim of the present study was to characterize the physicochemical and microbiological traits of the soils from MOVE project, managed according to two different agricultural systems (organic vs. conventional) and evaluating the effect of the crop (Brassica oleracea L. and Foeniculum vulgare M.) in a 10year field experiment. A multidisciplinary approach was applied, combining soil fertility indicators with phospholipid fatty acids analysis (PLFA) and PCR DGGE analysis (denaturing gradient gel electrophoresis).

\section{MATERIALS AND METHODS \\ FIELD EXPERIMENTS AND CROP MANAGEMENT}

The MOVE long-term experiment started in 2001 at Monsampolo del Tronto (AP), (latitude $42^{\circ} 53^{\prime} \mathrm{N}$, longitude $\left.13^{\circ} 48^{\prime} \mathrm{E}\right)$ a typical coastal area of Central Italy.

A 4-year crop rotation based on six main crops was established following conventional and organic systems. The rotation was: tomato (Lycopersicon esculentum Mill.), melon (Cucumis melo L.), fennel (Foeniculum vulgare M. var. azoricum), lettuce (Lactuca sativa L.), cauliflower (Brassica oleracea L. var. botrytis), and bean (Phaseolus vulgaris L.). Three different green manures were included in the rotation of the organic system: hairy vetch (Vicia villosa R.), grown before tomato transplanting, barley (Hordeum vulgare L.), grown before melon, and radish (Raphanus sativus L.), grown before lettuce.

The conventional and organic managements, located in neighboring fields of about $2200 \mathrm{~m}^{2}$ each, were separated by field margins and traffic infrastructure in order to avoid any cross-contamination effect between the systems. A 5-year period of conversion (2001-2006) was observed to ensure reliable long-term production goals and to overcome the effects of shortterm soil changes (Mazzoncini et al., 2010).

The soil of the conventional system was plowed to a depth of $0.4 \mathrm{~m}$ and the sowing or the transplanting beds were prepared by harrowing $(0.2-0.3 \mathrm{~m}$ deep, depending on the crop). The soil of the organic system was tilled by rotary spader and successively harrowed (0.1-0.2 $\mathrm{m}$ deep, depending on the crop). In the conventional system, weeds were controlled by the application of pre- or post-emergence/transplantation herbicides. In the organic system, an integrated weed management approach consisting of the use of green manures and of direct control methods (false-seed-bed, shallow harrowing and manual hoeing) was employed.

Conventional areas were fertilized with synthetic and mineral NPK fertilizers, while organic crops received off-farm organic fertilizers selected in accordance to the annex I of the European regulation (European Union, 2008). In Table 1 the amount of the nutritive elements of off-farm origin applied to the two systems during the entire rotation is shown. The plots were irrigated similarly both in conventional and organic systems, by sprinkler method (bean, cauliflower, fennel, and lettuce) or drip irrigation (tomato and melon).

\section{SOIL SAMPLING}

Soil samples were collected over the growing season 2010 on conventional and organic plots hosting cauliflower and fennels. Five replicate samples, each comprising of three replications, were taken randomly from each different block between the crop rows at one depth $(0-10 \mathrm{~cm})$ and immediately stored at $4^{\circ} \mathrm{C}$. Stones, large pieces of plant material and soil animals were removed before use. The samples were named as follows: ORG/FEN (organic management/Foeniculum vulgare), ORG/CAU (organic management/Brassica oleracea), CON/FEN (conventional management/Foeniculum vulgare), CON/CAU (conventional management/Brassica oleracea).

\section{SOIL CHEMICAL AND PHYSICAL PROPERTIES}

The dry weight was determined by placing $10 \mathrm{~g}$ of sample in an oven at $105^{\circ} \mathrm{C}$. The mass was held constant when the difference in values of the weights were less than $10 \mathrm{mg}$

Table 1 | Nutritive elements of off-farm origin applied to the organic and conventional system of the MOVE long term trial.

\begin{tabular}{lccccccc}
\hline & \multicolumn{3}{c}{ Organic } & & & \multicolumn{3}{c}{ Conventional } \\
\cline { 2 - 4 } \cline { 6 - 8 } Crop & $\mathbf{N}$ & $\mathbf{P}$ & $\mathbf{K}$ & & $\mathbf{N}$ & $\mathbf{P}$ & $\mathbf{K}$ \\
\hline Tomato & 176 & 35 & 24 & & 208 & 60 & 210 \\
Melon & 102 & 28 & 14 & & 112 & 48 & 169 \\
Fennel & 177 & 29 & 45 & & 208 & 39 & 100 \\
Lettuce & 132 & 15 & 22 & & 130 & 43 & 136 \\
Cauliflower & 184 & 50 & 43 & & 203 & 52 & 116 \\
Bean & 39 & 7 & 13 & & 44 & 35 & 80 \\
Rotation & 810 & 164 & 161 & & 905 & 276 & 811 \\
\hline
\end{tabular}

Values are reported in kg/ha and are the mean of 3 years (2007-2010). 
within an hour. Soil $\mathrm{pH}$ was measured in a $1: 1 \mathrm{w} / \mathrm{v}$ water. Physical and chemical characteristics were determined following the Official Methods of Analysis (AOAC, 2005) and were expressed as mean of three replications, each one was repeated twice.

\section{MICROBIAL COUNTS}

Soil microorganisms were extracted by shaking $10 \mathrm{~g}$ of soil in $90 \mathrm{~mL}$ of peptone water ( $\mathrm{pH}$ 7.2, Oxoid, Milan, Italy). After shaking conventional dilution spread-plating was performed to assess the total and specific cultivable bacterial and fungal communities. For this purpose the following media were prepared: Potato Dextrose Agar (PDA) for fungal count, Tryptone Soy Agar (TSA) for total bacterial count. Actinobacteria and nitrogenfixing bacteria were grown on two selective media: starch casein agar (Kuster and Williams, 1964) and Brown's glucose agar (Thompson, 1989), respectively. Plates were incubated at $28^{\circ} \mathrm{C}$ for fungi and bacteria. Nitrogen-fixing bacteria, total mesophilic microorganisms and fungi were detected after 3-6-10 days, while actinobacteria after 7 days. Data from triplicate counts were expressed according to the following equation: $\sum \mathrm{C} / \sum \mathrm{nz}$ where $\mathrm{C}$ is the number of colonies counted on the various plates considered, regardless of dilution, $\mathrm{z}$ is the dilution factor $\left(10^{-\mathrm{x}}\right)$ and $\mathrm{n}$ is the number of plates of each dilution (Cavalli-Sforza, 1966).

\section{PHOSPHOLIPID FATTY ACID ANALYSIS (PLFA)}

Lipids were extracted from soil, fractionated and quantified according to Bardgett et al. (1996). Separated fatty acid methyl esters were identified by chromatographic retention time and mass spectral comparison using bacterial acid methyl esters mix (FAME; Matreya 1114), methyl 10(Z)-heptadecenoate (Matreya 1203). The internal standard methyl non-adecanoate (Matreya 1029) was used to quantify data. Fatty acid nomenclature was used as described by Frostegard et al. (1993). The fatty acids i15:0, a15:0, 15:0, i16:0, 17:0, a17:0, i17:0, cy17:0, 16:1 $1 \mathrm{c}$ and cy19:0 were chosen to represent bacterial PLFAs (Dungait et al., 2011)

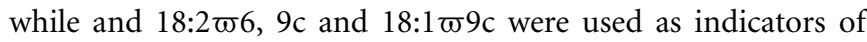
fungal community (Baath, 2003).

\section{EUMYCETIC COMMUNITY FINGERPRINTING BY PCR-DGGE}

DNA was extracted from soil samples using PowerSoil DNA Isolation Kit (MoBio Laboratories, Inc. Carlsbad, CA, USA) according to manufacturer's instructions. Quantification of total DNA was achieved using a VersaFluor fluorimeter and a Fluorescent DNA Quantitation Kit (Bio-Rad, Milan, Italy). PCR was performed using primers FR1-GC $\left(5^{\prime}-(G C)\right.$ AICCATTCAATCGGTAIT-3') and FF 390 (5'CGATAACGAACGAGACCT- $3^{\prime}$ ) according to Mello et al. (2010).

Gels were stained with ethidium bromide solution $(5 \mu \mathrm{g} / \mathrm{mL}$; $20 \mathrm{~min}$ ), washed with deionized water, and viewed by UV transillumination. Conversion, normalization, and further analysis of the DGGE patterns were carried out with Fingerprinting II Informatix $^{\mathrm{TM}}$ software program (Bio-Rad). Similarities among profiles were calculated using the Unweighted Pair-Group Method with Average (UPGMA) algorithm.

\section{SEOUENCING OF DGGE BANDS}

DGGE bands of interest were excised from the gel immediately after the staining in order to identify the dominant fungal populations. DNA from selected bands was put in distilled water and re-amplified with the primers FF 390 and FR1 (without GCclamp) as described above in a final PCR volume of $20 \mu \mathrm{L}$. The amplified fragment was then purified using GFX ${ }^{\mathrm{TM}}$ PCR DNA and Gel Band Purification Kit (Amersham Biosciences AB, Uppsala, Sweden), according to the manufacturer's instructions and after drying was delivered to BMR Genomics (Padua University, Padua, Italy) for sequencing. The obtained sequences were compared with those available at the National Center for Biotechnology Information (NCBI) using BLASTN (Altschul et al., 1990).

\section{STATISTICAL ANALYSIS}

Collected data regarding microbiological count, fatty acids and soil chemical and physical characteristics were subjected to twoway analysis of variance (ANOVA) using the R software $(R$ Foundation for Statistical Computing, Vienna, Austria). If the ANOVA detected significant differences, means separation was conducted through the Fisher's Least Significant Difference (LSD) test. The principal component analysis (PCA) was applied to summarize correlation among treatments (management systems/crops) and variables (soil chemical and microbial characteristics) using the statistical software STATISTICA for Windows (STAT. version 8.0, StatSoft Inc. Tulsa, OK, USA).

\section{RESULTS AND DISCUSSION}

\section{SOIL CHEMICAL AND PHYSICAL PROPERTIES}

The physical and chemical characteristics of the soils under investigation are reported in Table 2 . Generally, organic management showed significant larger values of several characteristics; organic matter content was $35 \%$ higher (17.3 vs. $12.7 \mathrm{~g} / \mathrm{kg}$ in organic and conventional, respectively) as well CEC (15.3 vs. 14.9 meq $100 / g$ in organic and conventional, respectively). Depending on soil type and climate, the capacity of a soil to store organic matter levels may be increased also in combination with the suitable soil management (Parton et al., 1996).

Regarding mineral availability, under organic management total and nitric nitrogen content increased over time. This is in accordance with Möller (2009) and Watson et al. (2002) who reported that the cycles of carbon $(\mathrm{C})$ and nitrogen $(\mathrm{N})$ are strongly linked, especially in sustainable agroecosystems. It is probably due to the characteristics of the soil $\mathrm{N}$ input of the organic system represented by organic fertilizers and green manure. These are more efficient in increasing the soil organic $\mathrm{N}$ pool overtime with respect to synthetic fertilizers (Watson et al., 2002; Möller, 2009).

Additionally, $\mathrm{K}, \mathrm{P}, \mathrm{Mg}, \mathrm{Mn}, \mathrm{Cu}$, and $\mathrm{Zn}$ were found in high concentrations in the organic managed soils; conversely, Fe was not influenced by soil management. Consequently the $\mathrm{C} / \mathrm{N}$ ratio was higher in conventional system (9.3 vs. 8.2).

Soil microorganisms govern the numerous nutrient cycling reactions in soils; the higher mineral availability in organic systems is a consequence of the higher microorganism activities (Oberson et al., 1993). Phosphorus, potassium, and magnesium fluxes through the microbial biomass is faster in organic soils, 
Table 2 | Chemical characteristics of soils under organic and conventional management.

\begin{tabular}{|c|c|c|c|c|c|c|c|c|c|c|c|c|c|c|c|}
\hline \multirow[t]{2}{*}{ System } & \multirow[t]{2}{*}{ Crop } & \multirow[t]{2}{*}{$p H$} & \multirow{2}{*}{$\begin{array}{c}\text { Organic } \\
\text { matter }^{\dagger}\end{array}$} & \multirow[t]{2}{*}{$\mathbf{N}$ tot $^{\dagger \dagger}$} & \multirow[t]{2}{*}{$\mathbf{N}$ nitric $^{\dagger \dagger}$} & \multicolumn{5}{|c|}{ Assimilable ${ }^{\dagger \dagger}$} & \multicolumn{2}{|c|}{ Exchangeable ${ }^{\dagger \dagger}$} & \multirow{2}{*}{$\begin{array}{c}C / N \\
\text { ratio }\end{array}$} & \multirow{2}{*}{$\begin{array}{c}M g / K \\
\text { ratio }\end{array}$} & \multirow[t]{2}{*}{$c E C^{\dagger \dagger \dagger}$} \\
\hline & & & & & & $\boldsymbol{P}$ & $F e$ & $M n$ & $\mathrm{Cu}$ & $Z n$ & $K$ & $M g$ & & & \\
\hline \multirow[t]{3}{*}{ Conventional } & Fennel & 8.2 & $12.9^{c}$ & $0.8^{c}$ & $5.7^{d}$ & $25^{d}$ & $12^{\mathrm{b}}$ & $3.6^{c}$ & $7.7^{d}$ & $1.2^{\mathrm{C}}$ & $347^{d}$ & $191^{d}$ & $9.4^{\mathrm{a}}$ & $1.8^{b}$ & $14.8^{b}$ \\
\hline & Cauliflower & 8.3 & $12.6^{d}$ & $0.8^{\mathrm{c}}$ & $9.7^{\mathrm{C}}$ & $32^{b}$ & $10^{c}$ & $3.4^{\mathrm{c}}$ & $11.1^{b}$ & $1.2^{\mathrm{C}}$ & $357^{c}$ & $242^{c}$ & $9.2^{b}$ & $2.2^{\mathrm{a}}$ & $14.9^{b}$ \\
\hline & Overall mean & 8.3 & $12.8^{\mathrm{B}}$ & $0.8^{\mathrm{B}}$ & $7.7^{\mathrm{B}}$ & $28^{\mathrm{B}}$ & 11 & $3.5^{\mathrm{B}}$ & $9.4^{\mathrm{B}}$ & $1.2^{\mathrm{B}}$ & $352^{\mathrm{B}}$ & $217^{\mathrm{B}}$ & $9.3^{\mathrm{A}}$ & 2.0 & $14.9^{\mathrm{B}}$ \\
\hline \multirow[t]{3}{*}{ Organic } & Fennel & 8.2 & $18.7^{a}$ & $1.4^{\mathrm{a}}$ & $13.5^{\mathrm{b}}$ & $27^{c}$ & $9^{d}$ & $4.5^{b}$ & $10.9^{c}$ & $1.7^{b}$ & $403^{b}$ & $273^{a}$ & $8.0^{d}$ & $2.2^{\mathrm{a}}$ & $15.9^{\mathrm{a}}$ \\
\hline & Cauliflower & 8.2 & $15.9^{b}$ & $1.1^{b}$ & $18.3^{a}$ & $39^{a}$ & $14^{a}$ & $5.1^{a}$ & $13.7^{\mathrm{a}}$ & $2.2^{\mathrm{a}}$ & $439^{a}$ & $243^{b}$ & $8.4^{c}$ & $1.8^{b}$ & $14.6^{c}$ \\
\hline & Overall mean & 8.2 & $17.3^{\mathrm{A}}$ & $1.2^{\mathrm{A}}$ & $15.9^{A}$ & $33^{A}$ & 11 & $4.8^{\mathrm{A}}$ & $12.3^{\mathrm{A}}$ & $1.9^{A}$ & $421^{A}$ & $258^{A}$ & $8.2^{\mathrm{B}}$ & 2.0 & $15.3^{A}$ \\
\hline s.e.d. & & 0.026 & 0.027 & 0.04 & 0.05 & 0.06 & 0.02 & 0.08 & 0.04 & 0.02 & 0.22 & 0.02 & 0.01 & 0.04 & 0.08 \\
\hline System & 1 & n.s. & $* *$ & $* *$ & $* *$ & $* *$ & n.s. & $* *$ & $* *$ & $* *$ & $* *$ & $* *$ & $* *$ & n.s. & $* *$ \\
\hline Crop & 1 & n.s. & $* *$ & $* *$ & $* *$ & $* *$ & $* *$ & $*$ & $* *$ & $* *$ & $* *$ & $* *$ & $* *$ & n.s. & $* *$ \\
\hline $\mathrm{S} \times \mathrm{C}$ & 1 & n.s. & $* *$ & $* *$ & $* *$ & $* *$ & $* *$ & $* *$ & $* *$ & $* *$ & $* *$ & $* *$ & $* *$ & ** & $* *$ \\
\hline
\end{tabular}

Different letters stand for statistically significant differences at $p<0.05$ (Fisher's LSD test).

t\%s.s; ${ }^{+t} \mathrm{mg} \mathrm{kg}^{-1}$; ${ }^{\mathrm{Ht}}$ Cation Exchange Capacity meq $100 \mathrm{~g}^{-1}$.

n.s., not significant.

${ }^{*}$ significant at $p<0.05$.

** significant at $p<0.01$.

and more minerals are normally bound in the microbial biomass (Oberson et al., 1996; Oehl et al., 2001). For all the mineral elements under organic system, except for $\mathrm{Mg}$ and $\mathrm{N}_{\text {tot }}$, areas cropped with cauliflower recorded higher values than fennel and lower values were recorded for organic matter, $\mathrm{Mg} / \mathrm{K}$ ratio $\mathrm{CEC}$ and $\mathrm{N}_{\text {tot }}$. Under conventional, in cauliflower areas we registered higher values of $\mathrm{N}-\mathrm{NO}_{3}, \mathrm{P}, \mathrm{Fe}, \mathrm{Cu}, \mathrm{K}, \mathrm{Mg}$, and $\mathrm{Mg} / \mathrm{K}$ ratio, while organic matter and $\mathrm{C} / \mathrm{N}$ ratio were lower.

\section{CULTIVABLE BACTERIA AND FUNGI}

The effects of long-term impact of soil management and crop production practices on the composition of soil microbial populations were studied. Plate counts are reported as mean values in Table 3. Total mesophilic bacteria were detected with a value of about $5 \log$ CFU/g with the only exception of organic soil cultivated with fennel showing a log higher (6 log CFU/g). Nitrogen fixing bacteria were not affected by the two management systems, while they significantly differed with crop $(p<0.05)$ and management $\mathrm{x}$ crop interaction $(p<0.05)$. Several studies have indicated that microbial diversity is affected by crop species and rotation due to differences in root exudation that stimulate microbial growth in the rhizosphere (Wasaki et al., 2005; Micallef et al., 2009). Soil management and crop species significantly affected the number of actinobacteria with the organic treatment showing the highest values. Actinobacteria are involved in organic matter turnover and carbon cycling. They can decompose some recalcitrant carbon sources including cellulose and chitin (Fließbach et al., 2007; Li et al., 2012). Cultivable fungi were $<10^{2} \mathrm{CFU} / \mathrm{g}$ in both systems even if they are a versatile group able to adapt and grow under extreme environmental conditions (Anand et al., 2006). Probably, culture conditions are very simple and homogeneous, in stark contrast to natural environments. So it is very difficult to quantitatively describe a fungal community using plate counts (Ritz, 2007).
Table 3 | Total mesophilic bacteria, nitrogen-fixing bacteria and actinomycetes in soils as affected by long term management (conventional vs. organic) and crop species.

\begin{tabular}{llccc}
\hline System & Crop & \multicolumn{3}{c}{ CFU/g } \\
\cline { 3 - 5 } & & $\begin{array}{c}\text { Total } \\
\text { mesophilic } \\
\text { bacteria }\end{array}$ & $\begin{array}{c}\text { Nitrogen- } \\
\text { fixing } \\
\text { bacteria }\end{array}$ \\
\hline Conventional & Actinomycetes \\
& Fennel & $1.4 \times 10^{5}$ & $1.1 \times 10^{5}$ & $2.4 \times 10^{5 \mathrm{a}}$ \\
& Cauliflower & $1.2 \times 10^{5}$ & $1.1 \times 10^{5}$ & $1.3 \times 10^{5 \mathrm{~b}}$ \\
Organic & Overall average & $1.3 \times 10^{5 \mathrm{~B}}$ & $1.1 \times 10^{5}$ & $1.8 \times 10^{5 \mathrm{~B}}$ \\
\cline { 3 - 5 } & Fennel & $1.1 \times 10^{6}$ & $1.9 \times 10^{5 \mathrm{a}}$ & $1.6 \times 10^{6 \mathrm{a}}$ \\
& Cauliflower & $7.0 \times 10^{5}$ & $7.5 \times 10^{4 \mathrm{~b}}$ & $1.1 \times 10^{6 \mathrm{~b}}$ \\
s.e.d. & Overall average & $8.8 \times 10^{5 \mathrm{~A}}$ & $1.3 \times 10^{5}$ & $1.3 \times 10^{6 \mathrm{~A}}$ \\
\cline { 3 - 5 } & & 294289 & 33750 & 161618.6 \\
\hline System & & $* *$ & $\mathrm{n} . \mathrm{s}$. & $* *$ \\
Crop & & $\mathrm{n} . \mathrm{s}$. & $*$ & $*$ \\
S $\times$ C & & n.s. & $*$ & $\mathrm{n} . \mathrm{s}$. \\
\hline
\end{tabular}

Different letters stand for statistically significant differences at $p<0.05$ (Fisher's LSD test).

n.s., not significant.

${ }^{*}$ significant at $p<0.05$.

${ }^{* *}$ significant at $p<0.01$.

Crop management involves a wide range of practices which can impact on the fungal populations creating conditions either favorable or not to their growth (Menendez et al., 2001; Gosling et al., 2006). In accordance to our results, organic managements may fail to favor fungal communities even after several years (Scullion et al., 1998). Probably, the value of $33 \mathrm{mg} / \mathrm{kg}$ P found in organic soil samples was quite high and negatively influenced 
cultivable fungi growth, as suggested by Dekkers and van der Werff (2001).

\section{PLFA ANALYSIS}

The microbial community assessed using a lipid-based approach reflected the cultivable and uncultivable current living community, overcoming the disadvantages associated to conventional systems. Despite fungi not being detected using cultivation methods, fungal and bacterial PLFAs were reported for both microbial groups and are presented in Table 4. PLFAs profiles displayed significant differences between organic and conventional systems. PLFAs biomass was significantly higher in soils subjected to organic management showing values of 13.25 (ORG/FEN) and 10.24 (ORG/CAU) which were at least 8 times higher than those found in conventional soils (2.52 in CON/FEN and 4.37 in CON/CAU) (Table 4). In this study, the interaction between system and crop appeared to have a great impact on soil microbial community structure suggesting that they could generate different and unique ecological niches (Vallejo et al., 2012). Fungal

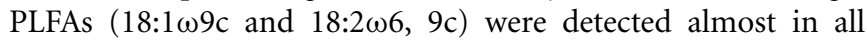
soil samples regardless of crop species. In particular, the fungal biomarker $18: 2 \varpi 6$, 9c ranged from 0.53 to $0.59 \mathrm{nmol} / \mathrm{g}$ in organic cauliflower and fennel, respectively, while it was absent in conventional soil samples. The second fungal PLFA, 18:1 $1 \mathrm{c}$, was present in conventional soils, even if at significant lower concentration than in organic soils (average value 0.54 vs. 1.47, respectively). However, this PFLA is also associated to Gram positive bacteria (Frostegard et al., 1993). Determining the reason for the presence of fungi in organic system is complex because the mechanisms involved in the soil re-colonization and the time required are unknown (Gosling et al., 2006). In this study, long-term organic management positively influenced uncultivable fungal concentration. Probably, the increase in $\mathrm{C}$ registered in the organic soil could have led to increased fungal biomass as reported by other authors (Kandeler et al., 1999;
Marschner et al., 2003). The concentrations of Gram positive (i15:0, a15:0, i16:0, i17:0, a17:0) and Gram negative (15:0, 17:0,

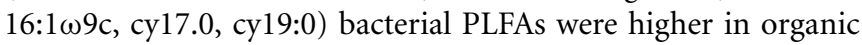
soils, in fact their presence have been related to quality of organic matter. In particular, high proportion of Gram negative bacteria is correlated to a shift from oligotrophic to more copiotrophic conditions in the soil (Yao et al., 2000; Kourtev et al., 2002).

Total anaerobic bacteria (cy17:0 and cy19:0 biomarkers) were influenced by soil management and were significantly higher in samples collected from soil fertilized with green manure and organic fertilizer. Moreover, cy17:0 specific biomarker of sulfate reducing bacteria (Desolphobacter sp.), within the conventional system, was influenced by the crop with values of 0.17 in CON/FEN and 0.40 in CON/CAU (Table 4). In the conventional system the highest percentages of microbial biomarkers were found in soils cultivated with cauliflower, while in organic system in those cultivated with fennel, suggesting that the interaction between system and crop exerts a strong effect in shaping soil microbial community structure.

Comparison of Fungal/Bacterial ratio (F/B) is an indicator of changes in the relative abundance of these two microbial groups (Vallejo et al., 2012). In the conventional system the obtained values ranged from 0.15 (CON/CAU) to 0.24 (CON/FEN), while in the organic one they were 0.23 (ORG/CAU) and 0.18 (ORG/FEN) (Table 4). Generally, high values are reported in the soils subjected to organic management, and they are inversely proportional to $\mathrm{N}$ application rates (Kong et al., 2011). The relatively low $\mathrm{F} / \mathrm{B}$ ratios suggested the dominance of bacterial PLFAs in all soil samples which may have resulted from the low $\mathrm{C} / \mathrm{N}$ ratio in both management systems as reported in Table 2 .

\section{DETERMINATION OF FUNGI BY PCR- DGGE}

To develop a deeper understanding of "soil fungi sociology" in organic and conventional soils PCR-DGGE analysis was performed. It is well known that PCR-DGGE analysis represents a

Table 4 | Phospholipid fatty acids in soils as affected by long term management (conventional vs. organic) and crop species.

\begin{tabular}{|c|c|c|c|c|c|c|c|c|c|c|c|c|c|c|c|}
\hline \multirow[t]{2}{*}{ System } & \multirow[t]{2}{*}{ Crop } & \multicolumn{14}{|c|}{ Fatty acids (nmol/g dry weight soil) } \\
\hline & & $15: 0$ & $17: 0$ & i15:0 & a15:0 & i16:0 & i17:0 & a17:0 & $16: 1 w 9 c$ & Cy17:0 & 18:1w9c & Cy19:0 & $18: 2 w 6,9 c$ & Total & F/B \\
\hline \multirow[t]{3}{*}{ Conventional } & Fennel & 0 & $0.20^{c}$ & $0.32^{d}$ & $0.15^{d}$ & 0.13 & 0.22 & 0.20 & 0.42 & $0.17^{d}$ & 0.49 & 0.22 & 0 & $2.52^{d}$ & 0.24 \\
\hline & Cauliflower & 0 & $0.24^{c}$ & $0.83^{c}$ & $0.47^{c}$ & 0.26 & 0.31 & 0.35 & 0.66 & $0.40^{c}$ & 0.58 & 0.27 & 0 & $4.37^{c}$ & 0.15 \\
\hline & Overall average & $0^{\mathrm{B}}$ & 0.22 & $0.58^{\mathrm{B}}$ & $0.31^{B}$ & $0.20^{\mathrm{B}}$ & $0.27^{\mathrm{B}}$ & $0.28^{\mathrm{B}}$ & $0.54^{\mathrm{B}}$ & $0.29^{\mathrm{B}}$ & $0.54^{B}$ & $0.25^{\mathrm{B}}$ & $0^{B}$ & $3.48^{B}$ & 0.18 \\
\hline \multirow[t]{3}{*}{ Organic } & Fennel & 0.32 & $0.40^{a}$ & $3.02^{a}$ & $1.68^{a}$ & 0.84 & 0.72 & 0.71 & 2.21 & $0.73^{a}$ & 1.48 & 0.55 & 0.59 & $13.25^{a}$ & 0.18 \\
\hline & Cauliflower & 0.21 & $0.28^{b}$ & $1.81^{b}$ & $1.03^{b}$ & 0.68 & 0.62 & 0.69 & 1.60 & $0.67^{b}$ & 1.45 & 0.67 & 0.53 & $10.24^{b}$ & 0.23 \\
\hline & Overall average & $0.27^{\mathrm{A}}$ & 0.34 & $2.42^{\mathrm{A}}$ & $1.36^{A}$ & $0.76^{A}$ & $0.67^{A}$ & $0.70^{A}$ & $1.91^{\mathrm{A}}$ & $0.70^{\mathrm{A}}$ & $1.47^{\mathrm{A}}$ & $0.61^{A}$ & $0.56^{\mathrm{A}}$ & $11.77^{A}$ & 0.21 \\
\hline System & & $*$ & n.s. & $*$ & * & $* *$ & $*$ & $*$ & $*$ & $*$ & $* *$ & $* *$ & $* *$ & $* *$ & \\
\hline Crop & & n.s. & n.s. & n.s. & n.s. & n.s. & n.s. & n.s. & n.s. & n.s & n.s. & n.s. & n.s. & n.s & \\
\hline$S \times C$ & & n.s. & $*$ & $*$ & * & n.s. & n.s. & n.s. & n.s. & * & n.s. & n.s. & n.s. & * & \\
\hline
\end{tabular}

Different letters stand for statistically significant differences at $p<0.05$ (Fisher's LSD test).

* significant at $p<0.05$.

** significant at $p<0.01$.

n.s., not significant.

F/B, Fungal/bacterial ratio. 
powerful tool to profile the structure of microbial communities in environmental samples without cultivation and to highlight dominant microbial populations in response to environmental variations.

The obtained DGGE fingerprinting showed few definite bands for all the soil samples suggesting the presence of a limited number of dominant, ubiquitous and ecologically well-adapted fungi types (data not shown).

DGGE dendrogram obtained by analyzing the amplified $18 \mathrm{~S}$ rDNA fragments is shown in Figure 1. Using an arbitrary similarity level of $90 \%$ two clusters can be identified and the fingerprints clustered according to the crop instead of management system.

Selected DGGE bands were excised and re-amplified. The sequenced bands corresponded to two uncultivable fungi and a further eight fungal species as reported in Table 5. Moreover, a great number of faint bands indicated that many equally abundant populations characterized all soil samples. The sequence of these bands displayed similarity values lower than 85\% to reference sequences, so they were not considered in the analysis.

The arbuscular mycorrhizal fungus of the Glomus genus dominated in all soil samples. Its dominance has been reported in several ecosystems, ranging from forest (Wubet et al., 2003) to highly disturbed agricultural fields (Daniell et al., 2001). Only a member of Diversisporales (Gigaspora gigantea), which generally decreases with cultivation (Gosling et al., 2006), was detected.

Obtained results suggested a relationship between soil resilience and biodiversity as reported also by other authors (Elliott and Lynch, 1994). The absence of a high fungal diversity in organic soils is probably due the fact that long-term or chronic stresses could eliminate part of the microbial community selecting a small number of species tolerant of intensive farming practices. There are no available data indicating the mechanisms and the time required for re-colonization of agricultural land and our study indicated that 10 years of organic management are not enough to increase fungal biodiversity.

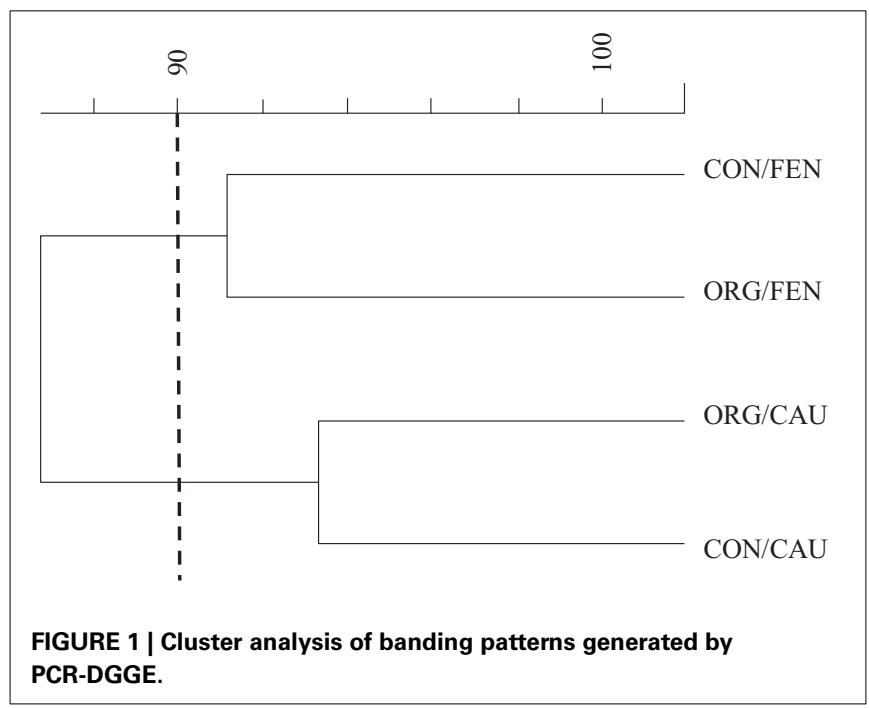

\section{PCA ANALYSIS}

The results of PCA analysis are shown in Figure 2; PC1 and PC2 captured $88.98 \%$ of the total data variability. The effect of management system clearly emerges from the bi-plot analysis: indeed, CON is distinctively separated by PC1 with respect to ORG, independently to the crop. While in CON the values of PCs are similar between fennel and cauliflower, in ORG system the two crops are separated by PC2. Cu, N nitric, $\mathrm{Zn}, \mathrm{K}, \mathrm{Mn}, \mathrm{P}$, aerobic mesophilic bacteria and cy 19:0 constitute a group well associated to ORG/CAU while organic matter, $\mathrm{CEC}, \mathrm{Mg}, \mathrm{N}_{\text {tot }}$, nitrogen fixing bacteria, i15:0, a15:0, i17:0, 16:1w9c, i16:0, and 18:2w6, 9c seems more associated with ORG/FEN.

Conventional soil samples are strictly correlated independently from the crop, in fact they are characterized by similar values of $\mathrm{C} / \mathrm{N}, \mathrm{N}_{\text {tot }}$, organic matter, $\mathrm{Mn}$ and $\mathrm{Zn}$. On the contrary the other two sites ORG/FEN and ORG/CAU are quite different. ORG/FEN is characterized by an higher content of organic matter, CEC, $\mathrm{N}_{\text {tot }}$ and $\mathrm{Mg}$. ORG/CAU is well differentiated from the others because of the content in $\mathrm{P}, \mathrm{K}, \mathrm{Fe}, \mathrm{Cu}$ and $\mathrm{Zn}$. This statistical approach confirmed that the crop influenced more the organic system that the conventional one.

\section{CONCLUSIONS}

This study contributes to the understanding of soil fertility status and microbial relationships with long-term soil managements (organic and conventional). Organic management showed higher value of organic matter, $\mathrm{N}$ as well as some important macro and micronutrients for crop growth. No cultivable fungi were detected in both systems, but PLFA analysis revealed an higher fungal biomass in organic management confirming the fundamental importance of $\mathrm{C}$ for soil microbial biomass development. Moreover, PCR-DGGE analysis revealed a low fungal biodiversity suggesting that long-term or chronic stresses could eliminate part of the microbial community which is difficult to be restored.

Table 5 | Identification of bands in DGGE profiles of fungal population from soils affected by long term management (conventional vs. organic) and crop species.

\begin{tabular}{|c|c|c|c|}
\hline Closest relative & $\%$ Identity & $\begin{array}{l}\text { Accession } \\
\text { number }\end{array}$ & $\begin{array}{l}\text { Isolation } \\
\text { source }\end{array}$ \\
\hline Arthrobotrys oligospora & 99 & AJ001987 & ORG/FEN, ORG/CAU, \\
\hline Paecilomyces lilacinus & 100 & GU980027 & CON/FEN, CON/CAU \\
\hline Glomus versiforme & 99 & EU164972 & \\
\hline Uncultured fungus & 98 & FM202457 & \\
\hline Gigaspora gigantea & 98 & EF014362 & \\
\hline Sebacina spp. & 98 & HO215802 & CON/CAU \\
\hline Glomus mossae & 100 & NG017178 & ORG/FEN, ORG/CAU, \\
\hline Uncultured soil fungus & 98 & FM202450 & CON/FEN, CON/CAU \\
\hline Glomus sp. & 98 & FR847093 & \\
\hline Acremonium kiliense & 100 & U43973 & $\begin{array}{l}\text { ORG/FEN, ORG/CAU, } \\
\text { CON/FEN }\end{array}$ \\
\hline
\end{tabular}




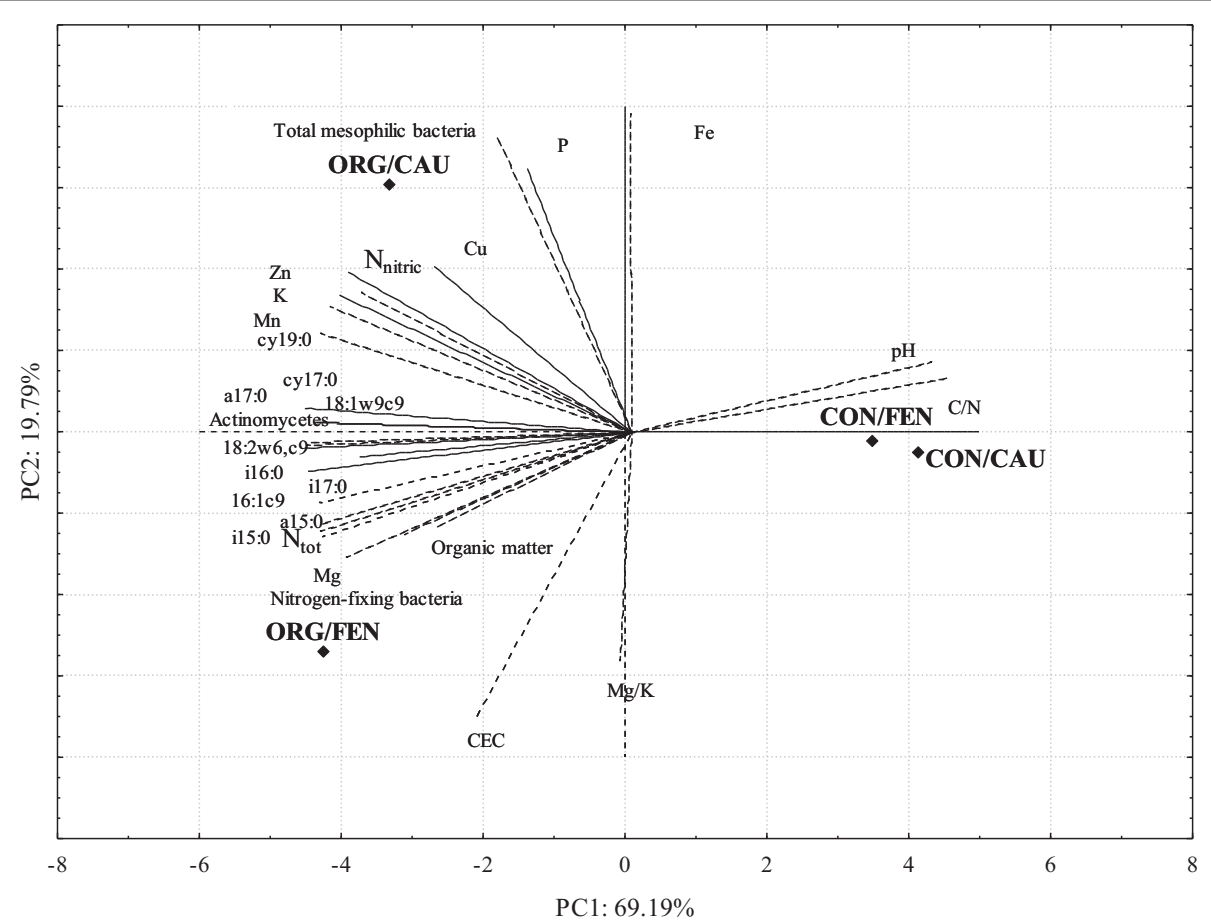

FIGURE 2 | Two principal component analysis (PCA) correlation bi-plot: rhombus stand for the standardized scores on PC1 and PC2 of four soil management/crop combinations (ORG/CAU, ORG/FEN, CON/CAU,
CON/FEN): lines represent the correlation between standardized variables (PLFAs, chemical and microbiological characteristics of soils) and PCs.
Further studies based on -omic approaches should be addressed to better understand the effects of different soil managements on soil fungal and bacterial functionality and community structure providing useful information for the development of more sustainable agricultural practices.

\section{REFERENCES}

AOAC. (2005). Official Methods of Analysis, 16th Edn. Washington, DC: Association of Official Analytical Chemists.

Altschul, S. F., Gish, W., Miller, W., Myers, E. W., and Lipman, D. J. (1990). Basic local alignment search tool. J. Mol. Biol. 215, 403-410. doi: 10.1016/S00222836(05)80360-2

Anand, P., Isar, J., Saran, S., and Saxena, R. K. (2006). Bioaccumulation of copper by Trichoderma viride. Bioresour. Technol. 97, 1018-1025. doi: 10.1016/j.biortech.2005.04.046

Baath, E. (2003). The use of neutral lipid fatty acids to indicate the physiological conditions of soil fungi. Microb. Ecol. 45, 373-383. doi: 10.1007/s00248-0032002-y

Bardgett, R., Hobbs, P. J., and Frostegård, A. (1996). Changes in soil fungal:bacterial biomass ratios following reductions in the intensity of management of an upland grassland. Biol. Fert. Soils 22, 261-264. doi: 10.1007/BF00382522

Bengtsson, J., Ahnström, J., and Weibull, A. C. (2005). The effects of organic agriculture on biodiversity and abundance: a meta-analysis. J. Appl. Ecol. 42, 261-269. doi: 10.1111/j.1365-2664.2005.01005.x

Berry, P. M., Sylvester-Bradley, R., Philipps, L., Hatch, D. J., Cuttle, S., Raynes, F, et al. (2002). Is the productivity of organic farms restricted by the supply of available nitrogen? Soil Use Manage. 18, 248-255. doi: 10.1079/SUM20 02129

Bonilla, N., Cazorla, F. M., Martínez-Alonso, M., Hermoso, J. M., GonzálezFernández, J. J., Gaju, N., et al. (2012). Organic amendments and land management affect bacterial community composition, diversity and biomass in avocado crop soils. Plant Soil 357, 215-226. doi: 10.1007/s11104-012-1155-1
Bulluck, L. R., Brosius, M., Evanoylo, G. K., and Ristaino, J. B. (2002). Organic and synthetic fertility amendments influence soil microbial, physical and chemical properties on organic and conventional farms. Appl. Soil Ecol. 19, 147-160. doi: 10.1016/S0929-1393(01)00187-1

Campanelli, G., and Canali, S. (2012). Crop production and environmental effects in conventional and organic vegetable farming systems: the case of a long-term experiment in mediterranean conditions (Central Italy). J. Sustain. Agric. 36, 599-619. doi: 10.1080/10440046.2011.646351

Cavalli-Sforza, L. L. (1966). Population structure and human evolution. Proc. $R$. Soc. 194, 362-379. doi: 10.1098/rspb.1966.0038

Daniell, T. J., Husband, R., Fitter, A. H., and Young, J. P. W. (2001). Molecular diversity of arbuscular mycorrhizal fungi colonising arable crops. FEMS Microbiol. Ecol. 36, 203-209. doi: 10.1111/j.1574-6941.2001.tb00841.x

Dekkers, T. B. M., and van der Werff, P. A. (2001). Mutualistic functioning of indigenous arbuscular mycorrhizae in spring barley and winter wheat after cessation of long-term phosphate fertilization. Mycorrhiza 10, 195-201. doi: 10.1007/s005720000078

Dungait, J. A. J., Kemmitt, S. J., Michallon, L., Guo, S., Wen, Q., Brookes, P. C., et al. (2011). Variable responses of the soil microbial biomass to trace concentrations of ${ }^{13}$ C-labelled glucose, using ${ }^{13}$ CPLFA analysis. Eur. J. Soil Sci. 62, 117-126. doi: 10.1111/j.1365-2389.2010.01321.x

Elliott, L. F., and Lynch, J. M. (1994). "Biodiversity and soil resilience," in Soil Resilience and Sustainable Land Use, eds D. J. Greenland and I. Szabolc (Wallingford: CAB International), 353-364.

Fierer, N., and Jackson, R. B. (2006). The diversity and biogeography of soil bacterial communities. Proc. Natl. Acad. Sci. U.S.A. 103, 626-631. doi: 10.1073/pnas.0507535103

Fließbach, A., Oberholzer, H. R., Gunst, L., and Mader, P. (2007). Soil organic matter and biological soil quality indicators after 21 years of organic and conventional farming. Agric. Ecosyst. Environ. 118, 273-284. doi: 10.1016/j.agee.2006.05.022

Frostegard, A., Baath, E., and Tunlid, A. (1993). Shifts in the structure of soil microbial communities in limed forests as revealed by phospholipid fatty-acid analysis. Soil Biol. Biochem. 25, 723-730. doi: 10.1016/0038-0717(93)90113-P 
Gosling, P., Hodge, A., Goodlass, G., and Bending, G. D. (2006). Arbuscular mycorrhizal fungi and organic farming Agriculture. Agric. Ecosyst. Environ. 113, 17-35. doi: 10.1016/j.agee.2005.09.009

Hill, G. T., Mitkowski, N. A., Alrich-Wolfe, L., Emele, L. R., Jurkonie, D. D., Ficke, A., et al. (2000). Methods for assessing the composition and diversity of soil microbial communities. Appl. Soil Ecol. 15, 25-36. doi: 10.1016/S09291393(00)00069-X

Hughner, R. S., McDonagh, P., Prothero, A., Shultz, C. J., and Stanton, J. (2007). Who are organic food consumers? a compilation and review of why people purchase organic food. J. Consum. Behav. 6, 94-110. doi: 10.1002/cb.210

Kandeler, E., Stemmer, M., and Klimanek, E. M. (1999). Response of soil microbial biomass, urease, and xylanase within particle size fraction to longterm soil management. Soil Biol. Biochem. 31, 261-273. doi: 10.1016/S00380717(98)00115-1

Kong, A. Y. Y., Scow, K. M., Córdova-Kreylos, A. L., Holmes, W. E., and Six, J. (2011). Microbial community composition and carbon cycling within soil microenvironments of conventional, low-input, and organic cropping systems. Soil Biol. Biochem. 43, 20-30. doi: 10.1016/j.soilbio.2010.09.005

Kourtev, P., Ehrenfeld, J. G., and Haggblom, M. (2002). Exotic plant species alter the microbial community structure and function in the soil. Ecology 83, 3152-3166. doi: 10.1890/0012-9658(2002)083[3152:EPSATM]2.0.CO;2

Kuster, E., and Williams, S. T. (1964). Selection of media for isolation of streptomycetes. Nature 202, 928-929. doi: 10.1038/202928a0

Lairon, D. (2009). Nutritional quality and safety of organic food. a review. Agron. Sustain. Dev. 30, 33-41. doi: 10.1051/agro/2009019

Li, R., Khafipour, E., Krause, D. O., Entz, M. H., de Kievit, T. R., and Fernando, D. (2012). Pyrosequencing reveals the influence of organic and conventional farming systems on bacterial communities. PLoS ONE 7:e51897. doi: 10.1371/journal.pone.0051897

Lorenzo, P., Pereira, C. S., and Rodríguez-Echeverría, S. (2013). Differential impact on soil microbes of allelopathic compounds released by the invasive Acacia dealbata link. Soil Biol. Biochem. 57, 156-163. doi: 10.1016/j.soilbio.2012. 08.018

Mader, P., Fleissbach, A., Dubois, D., Gunst, L., Fried, P., and Niggli, U. (2002). Soil fertility and biodiversity in organic farming. Science 296, 1694-1697. doi: 10.1126/science. 1071148

Marschner, P., Kandeler, E., and Marschner, B. (2003). Structure and function of the soil microbial community in a long-term fertilizer experiment. Soil Biol. Biochem. 35, 453-461. doi: 10.1016/S0038-0717(02)00297-3

Mazzoncini, M., Canali, S., Giovannetti, M., Castagnoli, M., Tittarelli, F., Antichi, D., et al. (2010). Comparison of organic and conventional stockless arable systems: a multidisciplinary approach to soil quality evaluation. Appl. Soil Ecol. 44, 124-132. doi: 10.1016/j.apsoil.2009.11.001

Mello, A., Miozzi, L., Vizzini, A., Napoli, C., Kowalchuk, G., and Bonfante, P. (2010). Bacterial and fungal communities associated to Tuber magnatum-productive niches. Plant Biosyst. 144, 323-332. doi: 10.1080/ 1263500903374724

Menendez, A. B., Scervino, J. M., and Godeas, A. M. (2001). Arbucular mycorrhizal populations associated with natural and cultivated vegetation on a site of Buenos Aires province, Argentina. Biol. Fert. Soils 33, 373-381. doi: 10.1007/s003740000336

Micallef, S. A., Shiaris, M. P., and Colon-Carmona, A. (2009). Influence of Arabidopsis thaliana accessions on rhizobacterial communities and natural variation in rootexudates. J. Exp. Bot. 60, 1729-1742. doi: 10.1093/jxb/erp053

Möller, J. (2009). Gravimetric determination of acid detergent fiber and lignin in feed: inter laboratory study. J. AOAC Int. 92, 74-90.

Oberson, A., Besson, J. M., Maire, N., and Sticher, H. (1996). Microbiological processes in soil organic phosphorus transformations in conventional and biological cropping systems. Biol. Fert. Soils 21, 138-148. doi: 10.1007/BF00335925

Oberson, A., Fardeau, J. C., Besson, J. M., and Sticher, H. (1993). Soil phosphorus dynamics in cropping systems managed according to conventional and biological agricultural methods. Biol. Fert. Soils 16, 111-117. doi: 10.1007/BF00369411

Oehl, F., Oberson, A., Probst, M., Fliessbach, A., Roth, H. R., and Frossard, E. (2001). Kinetics of microbial P uptake in cultivated soils. Biol. Fert Soils 34, 31-41. doi: 10.1007/s003740100362

Parton, W. J., Ojima, D. S., and Schimel, D. S. (1996). "Models to evaluate soil organic matter storage and dynamics," in Structure and Organic Matter Storage in Agricultural Soils, eds M. R. Carter and B. A. Stewart (New York, NY: CRC Press Lewis Publishers), 421-443.
Reganold, J. P., Andrews, P. K., Reeve, J. R., Carpenter-Boggs, L., Schadt, C. W., Alldredge, J. R., et al. (2010). Fruit and soil quality of organic and conventional strawberry agroecosystems. PLoS ONE 5:e12346. doi: 10.1371/journal.pone.0012346

Reganold, J. P., and Dobermann, A. (2012). Comparing apples with oranges. Nature 485, 176-177. doi: 10.1038/485176a

Ritz, K. (2007). The platedebate: cultivable communities have no utility in contemporary environmental microbial ecology. FEMS Microbiol. Ecol. 60, 358-362. doi: 10.1111/j.1574-6941.2007.00331.x

Scullion, J., Eason, W. R., and Scott, E. P. (1998). The effectivity of arbuscular mycorrhizal fungi from high input conventional and organic grassland and grass-arable rotations. Plant Soil 204, 243-254. doi: 10.1023/A:10043193 25290

Stamatiadis, S., Werner, M., and Buchanan, M. (1999). Field assessment of soil quality as affected by compost and fertilizer application in a broccoli field (San Benito County, California). Appl. Soil Ecol. 12, 217-225. doi: 10.1016/S09291393(99)00013-X

Thompson, J. P. (1989). Counting viable Azotobacter chroococcum invertisols. II comparison of media. Plant Soil 117, 17-29. doi: 10.1007/BF02206253

Vallejo, V. E., Arbeli, Z., Terán, W., Lorenz, N., Dick, R. P., and Roldan, F. (2012). Effect of land management and Prosopis juliflora (Sw.) DC trees on soil microbial community and enzymatic activities in intensive silvo pastoral systems of Colombia. Agric. Ecosyst. Environ. 150, 139-148. doi: 10.1016/j.agee.2012. 01.022

van Diepeningen, A. D., de Vos, O. J., Korthals, G. W., and van Bruggen, A. H. C. (2006). Effects of organic versus conventional management on chemical and biological parameters in agricultural soils. Appl. Soil Ecol. 31, 120-135. doi: 10.1016/j.apsoil.2005.03.003

Vogel, T. M., Simonet, P., Jansson, J. K., Hirsch, P. R., Tiedje, J. M., van Elsas, J. D., et al. (2009). TerraGenome: a consortium for the sequencing of a soil metagenome. Nat. Rev. Microbiol. 7, 252. doi: 10.1038/nrmicro2119

Wasaki, J., Rothe, A., Kania, A., Neumann, G., Romheld, V., Shinano, T., et al. (2005). Root exudation, phosphorus acquisition, and microbial diversity in the rhizosphere of white lupine as affected by phosphorus supply and atmospheric carbon dioxide concentration. J. Environ. Qual. 34, 2157-2166. doi: 10.2134/jeq2004.0423

Watson, C. A., Bengtsson, H., Ebbesvik, M., Løes, A. K., Myrbeck, A., Salomon, E., et al. (2002). A review of farm-scale nutrient budgets for organic farms in temperate regions. Soil Use Manage. 18, 264-273. doi: 10.1079/SUM2002127

Wubet, T., Kottke, I., Teketay, D., and Oberwinkler, F. (2003). Mycorrhizal status of indigenous trees in dry Afromontane forests of Ethiopia. Forest Ecol. Manag. 179, 387-399. doi: 10.1016/S0378-1127(02)00546-7

Yao, H., He, Z., Wilson, M. J., and Campbell, C. D. (2000). Microbial biomass and community structure in a sequence of soils with increasing fertility and changing land use. Microb. Ecol. 40, 223-237. doi: 10.1007/s002480000053

Zhang, B., He, H., Ding, X., Zhang, X., Zhang, X., Yang, X., et al. (2012). Soil microbial community dynamics over a maize (Zea mays L.) growing season under conventional- and no-tillage practices in a rain fed agroecosystem. Soil Till. Res. 124, 153-160. doi: 10.1016/j.still.2012.05.011

Conflict of Interest Statement: The authors declare that the research was conducted in the absence of any commercial or financial relationships that could be construed as a potential conflict of interest.

Received: 18 September 2014; paper pending published: 20 October 2014; accepted: 07 November 2014; published online: 10 December 2014.

Citation: Stagnari F, Perpetuini G, Tofalo R, Campanelli G, Leteo F, Della Vella U, Schirone M, Suzzi G and Pisante M (2014) Long-term impact of farm management and crops on soil microorganisms assessed by combined DGGE and PLFA analyses. Front. Microbiol. 5:644. doi: 10.3389/fmicb.2014.00644

This article was submitted to Food Microbiology, a section of the journal Frontiers in Microbiology.

Copyright (c) 2014 Stagnari, Perpetuini, Tofalo, Campanelli, Leteo, Della Vella, Schirone, Suzzi and Pisante. This is an open-access article distributed under the terms of the Creative Commons Attribution License (CC BY). The use, distribution or reproduction in other forums is permitted, provided the original author(s) or licensor are credited and that the original publication in this journal is cited, in accordance with accepted academic practice. No use, distribution or reproduction is permitted which does not comply with these terms. 